\title{
Lumen
}

Selected Proceedings from the Canadian Society for Eighteenth-Century Studies

\section{Mme Riccoboni: 'philosophe parvenue'}

\section{Olga B. Cragg}

Volume 14, 1995

URI : https://id.erudit.org/iderudit/1012512ar

DOI : https://doi.org/10.7202/1012512ar

Aller au sommaire du numéro

Éditeur(s)

Canadian Society for Eighteenth-Century Studies / Société canadienne d'étude du dix-huitième siècle

ISSN

1209-3696 (imprimé)

1927-8284 (numérique)

Découvrir la revue

Citer cet article

Cragg, O. B. (1995). Mme Riccoboni: 'philosophe parvenue'. Lumen, 14, 109-118.

https://doi.org/10.7202/1012512ar d'utilisation que vous pouvez consulter en ligne.

https://apropos.erudit.org/fr/usagers/politique-dutilisation/ 


\section{Mme Riccoboni: 'philosophe parvenue'}

Mme Riccoboni's fifth and last epistolary novel, Lettres de Mylord Rivers à Sir Charles Cardigan, published in 1771, is frequently grouped with her other sentimental narratives in letter form without distinguishing its special nature. In fact, it is only within the last decade that scholars began to find subversive and serious overtones to her writing. ${ }^{2}$ When they did not simply ignore it, critics previously considered much of her work as pedestrian products that were categorized as 'vanilla' literature of the period. ${ }^{3}$ Should we view this novel, then, as another example of lightweight sentimental fiction with a typically 'euphoric' (to borrow the term coined by N. Miller) ${ }^{4}$ plot, or is there a possibility of placing it within a larger context of the intellectual turmoil of the period? Is it a female version of the masculine 'philosophical' novel? ? $^{5}$

Certainly one can find here the classical discourse of the philosophes (based on underlying critical assumptions about the ancien régime) that has come to be associated with the Enlightenment, but it appears in a modified form. The questioning of the social, political, and moral structures, as well as of the literary trends of French society of the second half of the eighteenth century, can be viewed as the subtext of this novel. Mme Riccoboni's role as a proselytizer of the philosophes' humanitarian goals has been neglected, partly because of her own subversive attitude toward them. We can see a parallel in the similarly slow recognition of the 'philosophical' contribution of Mme de Graffigny's Lettres d'une Péruvienne. ${ }^{6}$ Mme Riccoboni's mild, non-aggressive tone, totally in keeping with the self-effacing style required of women writers of her day, has earned her the reputation of being a dissector of the human heart, rather than a critic of the ancien régime. An exploration of Mme Riccoboni's real but ironic connections with the philosophes will lead me to examine her own struggle with their goal of harmony between the self and others, as it is reflected in the Lettres de Mylord Rivers.

What was Mme Riccoboni's direct participation in the intellectual scene of her day and what were her contacts with the Enlightenment writers? At the beginning of her creative period around 1761 (after she had abandoned her career as an actress with the Comédiens Italiens), her 
correspondence informs us that she frequented the salon of the materialistic philosopher baron d'Holbach and Helvétius. ${ }^{7}$ In this milieu, she became acquainted with David Hume, Diderot and David Garrick. She corresponded with the latter regularly for twelve years from 1765 to 1777; we should also remember her epistolary exchange with Diderot. Adam Smith and Edward Gibbon were among her visitors in the rue Poissonnière, while her close association with the Laclos family is evidenced by her famous correspondence with the author of Les Liaisons dangereuses. Mme Riccoboni's letters show that she knew many of the prominent personalities of her day, but after her initial participitation in the salons, she later preferred not to mingle with the intellectual élite of her time.

The type of social interaction that made serious discussions depend on a display of wit, glitter and charm did not appeal to her. Already in 1766, she complained to David Hume about the dryness, sterility and formality of society:

I detest the ceremonious commerce where friendship is never introduced, dissertation bores me, and witty women are odious to me. Gaiety, sweetness, lack of affectation, sentiment, this is what interests me. ${ }^{8}$

Her critical attitude here is similar to Rousseau's well-known dislike of Parisian affectation and insincerity.

With the passage of time, Mme Riccoboni withdrew deliberately to her own restricted circle of the rue Poissonnière. Ironically, however, philosophes like Rousseau or Voltaire never left her at peace. In the Rousseau-d'Holbach-Hume quarrel, she had supported d'Holbach's cabal against Rousseau. In 1766 Mme Riccoboni wrote to Garrick about Rousseau's hypocrisy, egoism and narcissism: 'Is he not very inconsistent and does he not at all contradict his principles?' ${ }^{\prime 9}$ Jean-Jacques's paranoid psyche clearly stands out in the following anecdote about him. The unpredictable actions of this 'strange animal' (as Mme Riccoboni called him) offended her friend Mme Bret, wife of the dramatist and critic Antoine Bret, so much that Marie Jeanne felt compelled to relate the following scenario to Sir Robert Liston:

Monsieur Bret, to satisfy his wife, visits the philosopher, his old friend Rousseau. He invites him, begs him and to better commit him, tells Jean-Jacques that his wife has a portrait of him, that she likes like her very own eyes. What portrait, asks Rousseau, is it the one in which I am pictured in an Armenian costume? Yes, says the loving husband. She adores this charming portrait. 'Leave my house instantly!' replies Rousseau, furious. A portrait made to dishonour and 
vilify me! I never want to see this woman capable of looking at it, of preserving this monument of my shame! I would prefer to die than to dine with her. ${ }^{10}$

The initial hostility expressed by Mme Riccoboni toward Rousseau is indeed ironic. In behavior and thought, the philosopher of the Social Contract is a mirror image of Marie Jeanne's own tendencies.

If I were young I would like to inhabit the woods, take lessons from Jean-Jacques, walk on four legs, live with honest tigers, more reasonable than their alleged king. ${ }^{11}$

Her whimsical temperament, pronounced individualism, and non-conformism were only too similar to Rousseau's mercurial outbursts. Mme Riccoboni's vulnerability and a certain misanthropy, just like her avowed enemy's, pushed her toward isolation. While Voltaire never appears as an acquaintance or actor in Mme Riccoboni's correspondence, she nonetheless targeted his writings for their combative tone and criticized his work for repetition of ideas. ${ }^{12}$ After her attacks on the philosophes, it does not surprise us that Mme Riccoboni's personal ambivalence about the role and limitations of philosophy are echoed in her fiction.

The opening of the Lettres de Mylord Rivers centers on the very subject of the role of philosophy in human affairs. Like Mme Riccoboni's disdain for it in real life, Mylord Rivers refuses to accept the title of philosopher: 'Please, never call me wise nor a philosopher. I have often heard you call a pedant or a boor by these two epithets. ${ }^{, 13}$ Ironically, this condemnation of philosophy at the beginning of the novel does not preclude all the protagonists from exercising that very art themselves. Mylord Rivers enjoys speculating about the important issues of life and it is his questioning turn of mind, applied to the complex social realities, that partly identifies him with the literary type of the philosophe. In fact, at the end of the novel, he frankly admits having enjoyed this penchant for philosophizing since the age of twenty.

It is useful to remember that in the early 1730 s and 1740 s, attacks on the prototype of the philosopher were not uncommon on the French stage and in the journalistic venues such as the Mercure de France and the Journal de Trévoux. This image changed, however, in mid-century after Diderot's Encyclopédie presented a modified and more conservative view of the philosopher. ${ }^{14}$ Mme Riccoboni's novel hints at the subtle transformation that this portrait undergoes in the literature of the period.

The protagonist's early indication of his interests in the important questions of philosophy, as well as social and literary issues in France, invites the reader to view the Lettres de Mylord Rivers as a novel of the Enlightenment. ${ }^{15}$ Indeed, the two centers of this work move in opposite 
directions and show the conflict between the inner needs of the individual and the social tendencies of man. Within the context of the French Enlightenment, these two axes converge in various degrees to produce a unifying objective for the improvement of society and the individual in it. ${ }^{16}$ Mme Riccoboni's social, political, and cultural ideas merge into the major theme of happiness which had become a unifying thread in the French Enlightenment. The structural coherence of the Lettres de Mylord Rivers as a novel of ideas can be found in a statistically rich linguistic field that centers on words such as 'happiness' (used 53 times), 'felicity' (14), 'happy' (57), 'content' (9), 'satisfaction' (7) and 'joy' (19), all pointing to a common denominator. On the surface, it appears to cover the emotional inclinations and needs of Mme Riccoboni's protagonists, but these signifiers spill over into ideological considerations. Mylord Rivers himself possesses a sharp awareness of the polyvalence of his concept of the existential notion of inner peace: 'My ideas about happiness constantly change' (164), he writes to Lady Orrery. Indeed, his own definition of happiness evolves from a broad view, applied to the well being of others in society, to a personal recognition of his own inner needs. We shall examine how the dialectic of love (idealized, romantic love, viewed as illusion, is opposed to love as a genuinely shared feeling) will transform the concept of well-being and thereby place the existential discourse in a non-conventional perspective.

The initial step in the search for an ideal harmony is based on a dream of happiness where justice and equality exist for all men, albeit in an imperfect world. It is a short-lived ideal that Mylord Rivers replaces with a critique of a false happiness, based on appearances which, later, is also discarded for its faulty facade. The penultimate stage of his search is expressed by the realization that contentment can be found in nature (where passions are soothed), and an awareness develops that philosophic wisdom can intervene in the turmoils of the day to bring satisfaction. His final answer is the outcome of an arduous search, attained with difficulty in a society that pushes the individual to live according to the standards of others, and where conformity and hypocrisy are de rigueur. The problem, according to Rivers, is not so much the weakness of the individual, incapable of sustaining the pressures of society, as the monumental forces of conditioning that pressure him into subservience: 'Yes, without a doubt, education, prejudices, example of others, lead us to neglect real benefits (biens réels) for benefits of conventions' (156). The directness and frankness of this observation resembles Rousseau's criticism of society and recalls the emergence of 'l'homme de l'homme' (man as invented and defined by society) by contrast to natural man who does not seek satisfaction outside of self. ${ }^{17}$ 
The topos of happiness, a complex and subtle concept, pervades all levels of this work. It consists of an inner well-being, contentment of the mind and spirit, domestic bliss and a socially oriented awareness propelled by altruistic desires and social justice. Its expression is embodied in three main characters: the widow, Milady Orrery, Miss Rutland, and Mylord Rivers. As is the case in many traditional novels of the period, Mme Riccoboni's meditations on this issue fall within the hackneyed marriage plot with many casual references in the Lettres de Mylord Rivers to 'impending happiness' structured within the parameters of matrimony. In this text, however, Mme Riccoboni examines its various forms much more systematically than in her previous works.

Throughout the novel, the role of marriage is explored as a means of achieving an ideal state of stability. The romantic image of perfect bliss seems to be nostalgically rooted for Mme Orrery, a widow of eleven years, in the dream of a shared union:

What is freedom, and peace, compared to the fantastic pleasures that I conjure up! I wonder secretly if independence makes me happy, if love is not the real good? If to inspire and share it is not the greatest and unique happiness of life? (56)

The interrogative form of the sentence suggests reservations and mistrust about it. In fact, it is only after certain conditions have been met, to assure permanency, that the stereotyped 'lived happily after' conclusion is reached, and this resolution appears to be more of a concession to convention than a reality. Hesitancy and negative deliberation throughout the entire novel seem to undermine the verisimilitude of the closed plot.

A parallel discourse can be detected in Adeline Rutland's attitude to matrimony. She bluntly dissociates herself until the very end from tying the knot. She scoffs sarcastically at the model offered by her married sister by undermining the veracity of her words: 'The example of my happy sister was supposed to make me run to the altar,' (73) she muses unconvinced. Her resistance to the bonded state is based on an inner doubt and scepticism about the possibility of a relationship grounded in communication of feelings.

Not all of the female characters find themselves in a free situation, either through widowhood or stemming from an orphaned state, which would give them the choice to resist. In the case of Mlle de Layrac (the heroine of a long interpolated story), the obligations of a dutiful daughter carry her through life: 'She saw herself in the harsh necessity of obeying, of sacrificing all her hopes of happiness to a duty from which nothing could dispense her' (104). The family 'good' represents an 
all-powerful force which overpowers her personal drive to disengage from bonding.

The second variation of happiness in the Lettres de Mylord Rivers corresponds to the eighteenth-century concept of 'bienfaisance', which is linked to self-satisfaction and obtained from altruistic actions in helping others to achieve contentment. ${ }^{18}$ For example, by a generous dowry gift to her niece, Lady Orrery is instrumental in allowing her marriage to take place. Her own self-knowledge, learned through introspection, has taught her how to achieve self-fulfillment. This action results in an enjoyment akin to an almost sensuous pleasure, a personal enrichment brought about by a rational approach to generosity, attaching virtue to a sentimental good conscience, so typical of the social morality of this period.

The more serious philosophic meditation on happiness stands within the Rousseauist dichotomy of 'being and appearing' ('l'être et le paraître' to use Starobinski's phrase). Mylord Rivers, the renegade philosopher, examines rationally the different means by which people seek personal gratification. One by one, he eliminates all rewards received from choices made exterior to self, such as the compensation of high office or the accumulation of material possessions. Mme Riccoboni dramatizes Mylord Rivers' ideas by structuring them in the familiar patriarchal, sententious discourse which gives them weight and substance:

Happiness does not appear to me at all to be attached to a situation, but to an idea that we form of our own situation and that of others. Real needs are so limited that it would be easy to be happy if we looked at ourselves alone. But constantly wounded by objects of comparison, our eyes close on our own advantages, our heart opens up to desire; glamour and splendour dazzle us, and the person who flaunts them in our eyes makes us feel the deprivation of an infinity of worldly goods that perhaps one does not enjoy. (84-85)

This key passage clearly outlines the author's definition of happiness, which hinges on three components: the individual's relationships with others, his view of human nature, and his perception of reality.

Mme Riccoboni's realism suggests that human nature, because of its frailty, depends more on the judgement of others than on one's own. Instead of centering on what is around the self, man tends to turn his glance toward objects that are exterior to him. The envious desire, henceforth, becomes the source of the divided self. The satisfaction comes more from the reflection by others of what is possessed rather than emanating from the inner self. 
Here the rich and the great know little the charms of domestic felicity, of a true inner happiness, of independent and glamorous exteriors which everywhere offer the perfect picture. In Paris people gladly sacrifice the enjoyments of the soul to vanity, and the French seek less, I think, to feel happy than to appear it.(157)

The criticism of society's short-lived gratification, derived from vanity, is reminiscent of Rousseau's condemnation of la bonne société. This indictment is again expressed in the guise of a worldly discourse to underscore its collective and universal nature.

A return to self, or rapprochement de soi, bringing harmony in life, can also be achieved through pleasures in nature. Although Mme Riccoboni recognizes the mythic dimensions of this utopia as a literary construct, her protagonist nonetheless insists on its real advantages. The self-centering of the soul and the calm that follows bring enjoyment which is linked to the plenitude of existence. Thus in the Lettres de Mylord Rivers two images representing two lifestyles are contrasted: the worldly state, characterized by a movement toward the outside, is opposed to the rustic life which promotes contemplation and meditation. The dream of happiness as a return to the inner resources ironically overlaps with the deepest Rousseauist aspirations for intimacy. The comparison between imaginary happiness based on appearances (bonheur chimérique), and true happiness grounded in the inner man, reveals Mylord Rivers' awareness of different possibilities in his search for truth:

Every person ... experiences in the presence of woods, waters, cultivated plains, this gentle and sensitive movement which moves us to withdraw inside, reminds us of the initial organization of nature, warns man that he underestimates its order and changes its design; it shows him where inner peace lies, this happiness to which every thinking being aspires; a happiness always desired, vainly sought in the midst of tumult and noise. (77)

Reason paves the road to nature, where peace is found.

After Mylord Rivers has considered the anti-social solution, based on solitude, independence and withdrawal from others - what Mme Riccoboni calls an 'exhilaration which charms the senses' - the ultimate image of a perfect state is rooted in the recognition of the need of reciprocity while maintaining difference. He reflects: 'My delicate disposition made me think that love alone could fill it' (165). Mylord Rivers' 'delicious sentiment', based on esteem and trust, appears to be a revelation of the utmost simplicity, but it is the rational result of a heuristic journey, practised by the philosophes both in fiction and non-fiction.

In Mme Riccoboni's early novels, Lettres de Fanni Butlerd or the Lettres de Juliette Catesby, the quest for a philosophic self-discovery was carried 
out exclusively by women and often in conflict with the sensual needs of men. In her last novel, however, she takes advantage of the epistolary form which allows a more balanced presentation of the complex forces of rationalism and conformism from the multiple perspective of the male and female. Unlike the male protagonists of her early novels, who are made to dwell on their selfish drives, Mylord Rivers exclaims: 'It is indulgence and kindness that prepares two satisfied lovers in replacing the transient tenderness of love by the lasting feeling of a solid friendship' (129). The achieved union is not based on the illusion of the senses but on mutual understanding and the transcendence of the ephemeral play of seduction. It is significant that the voice offering this message is male, for it links Mylord Rivers to the philosophes and their belief in the enlightenment of humanity.

Mme Riccoboni's indictment of the embedded patriarchal structures and conventions of society, in the tradition of Montesquieu and Mme de Graffigny, ${ }^{19}$ is voiced particularly strongly when she observes that the foundation of the family unit is based on injustice and prejudice. She questions not only the right of primogeniture (which favors the eldest male in the family), but also the authority that parents exercise in the marital destiny of their female offspring. In the arena of political action, she moves further afield to the New World where she sees the figure of the hypocritical philosopher chastizing as much as Voltaire did Europeans for their exploitation of slaves while practising the very same evils at home. She mocks these enlightened thinkers for their double standards: their idealistic aspirations for the improvement of the human race are blatantly opposed to the neglect of duties and responsibilities close at hand. Thus Mylord Rivers writes to his pretentious false philosopher:

If only each man made himself a law of fulfilling the duties that nature and society impose on him, general good would simply be born from this uniform disposition. (40)

Again, in the philosophic tradition of fictionalized critical prose exemplified in Voltaire's Lettres philosophiques, we hear Mme Riccoboni's voice, similar in reproach, becoming the arbitrator of good and bad taste. The classical standards of her aesthetic and moral values give rise to her deep dislike of the unbridled exaggeration of sensibility, linked to a self-righteous goodness, which was in vogue throughout Europe in the second half of the century:

But what will lead me, I believe, to stop reading, it's this common mania to writers of all genres, of all nations; it's this fury, this rage for virtue which excites 
in them passions approaching folly. What, not being able to write ten lines without exclaiming, o goodness! o charity! o humanity! o vertu! (175)

The unrestrained expression of pre-romantic feelings went against Mme Riccoboni's sense of decorum.

Within the broader concept of what constitutes a novel of the Enlightenment, the Lettres de Mylord Rivers has gained its lettres de noblesse. My premise that this novel can be viewed as a vehicle of ideas and that Mme Riccoboni can be envisaged as a woman philosopher, has found an echo in a recent comment on her role in the history of ideas:

Those who followed in the wake of this new philosopher, men like Diderot, but especially women like Marie-Jeanne Riccoboniand Isabelle deCharrière ... would come to face the inevitable dilemma that pits civility and, if not social order, then social conformity against the possibility of revision and free expression. ${ }^{20}$

The conflict between orthodox thinking, rationalistic philosophy, and the urge for spontaneity in freedom of choice produces the subtle underlying tension that characterizes Mme Riccoboni's last novel. Mme Riccoboni's position in the literary map of her time as an author, not only of sensibility but also of more serious intent, establishes a permanent role for her in the French Enlightenment.

\section{OLGA B. CRAGG}

The University of British Columbia

\section{Notes}

1 Mme Riccoboni, Lettres de Mylord Rivers à Sir Charles Cardigan, ed. Olga B. Cragg (Geneva: Droz, 1992). All references given in parentheses are to this edition. The translation is mine.

2 The work of E. H. Cook, 'Going Public: The Letter and the Contract in Fanni Butlerd', Eighteenth-Century Studies 24 (1990): 21-45 and J. H. Stewart, Gynographs: French Novels by Women of the Late Eighteenth Century (Lincoln and London: Nebraska UP, 1993) 70-96 are the best examples of the illuminating criticism done on Mme Riccoboni's open-ended fiction.

3 Even in the most recent complete study on Mme Riccoboni's ideas Mireille Flaux argues that the Lettres de Mylord Rivers belongs to the the classical tradition of the psychological novel, although she admits passing by the influence of Montesquieu's epistolary novel on it. Madame Riccoboni: Une idée du bonheur au féminin au siècle des lumières (Lille: Université de Lille III, Atelier national de reproduction des thèses, 1991) 14.

4 N. Miller, The Heroine's Text: Readings in the French and English Novel, 1722-1782 (New York: Columbia UP, 1980). 
5 This question could not be addressed in the introduction to my critical edition of the novel.

6 J. G. Altman, 'Making Room for "Peru": Graffigny's Novel Reconsidered,' Dilemmes du roman, ed. C. Lafarge. Stanford French and Italian Studies 65. (Stanford: Anima Libri, 1989) 33-45. The most recent somewhat mixed claim for Zilia being a spokeswoman of the Enlightenment is by D. J. Adams, 'The Lettres d'une Péruvienne: Nature and Propaganda', Forum for Modern Language Studies 38 (1992): 121-29.

7 On this salon see A. C. Kors, D'Holbach's Coterie: An Enlightenment in Paris (Princeton: Princeton UP, 1976).

8 Mme Riccoboni's Letters to David Hume, David Garrick and Sir Robert Liston: 1764-1783, ed. J. C. Nicholls Studies on Voltaire and the Eighteenth Century 149 (1976): 344 . The translation is mine.

9 Nicholls, 81 .

10 Nicholls, 162 . This episode seems to be unknown or generally ignored by Rousseau's biographers.

11 Nicholls, 348 .

12 'Never has anyone made more pitiful books now than Voltaire. Philosophy is turning all of our fools' heads; they pretend to shove it into their dull productions. Stupidity one could accept, but these flat productions batter you to death. It's Voltaire and Montesquieu chopped up into pieces by ignoramuses. Voltaire harps non stop. He has just published 9 volumes to serve as a continuation to the Encyclopédie. D'Holbach agrees with me that one would have difficulty coming up with one passable volume in 12 out of the 9 volumes in octavo'; Nicholls, 288.

13 Nicholls, 262.

14 Jack Undank, 'Portrait of the Philosopher as a Tramp,' A New History of French Literature, ed. Denis Hollier (Cambridge: Harvard UP, 1989) 423.

15 Miraille Flaux's excellent, but unfortunately not readily accessible, thesis cited above (n.3) occasionally refers to various aspects of my topic, but it is not studied systematically.

16 Robert Mauzi, some twenty-five years ago, in his epoch-making study, entitled L'Idée du bonheur, surprisingly made only one reference to a novel by Mme Riccoboni on the idea of happiness, namely the Lettres de Milady Catesby.

17 'The savage lives within himself, while social man lives constantly outside himself, and only knows how to live in the opinion of others, so that he seems to receive the consciousness of his own existence merely from the judgment of others concerning him.' J.-J. Rousseau, A Discourse on the Origin of Inequality, trans. G. D. H. Cole (London, Melbourne, and Toronto: Dent, 1982) 104.

18 This is how the term was used by philosophes such as l'abbé de Saint-Pierre. See Lettres de Mylord Rivers 52 n. 21.

19 See Lettres de Mylord Rivers 65 n. 33.

20 Undank (n. 14) 424. 